\title{
Adsorption of Metal Ions on Novel 3- $n$-Propyl(Methylpyridinium) Silsesquioxane Chloride Polymers Surface. Study of Heterogeneous Equilibrium at the Solid-Solution Interface
}

\author{
Hérica A. Magosso, ${ }^{a}$ Natália Fattori, ${ }^{a}$ Yuriy V. Kholin ${ }^{b}$ and Yoshitaka Gushikem ${ }^{* a}$ \\ ${ }^{a}$ Institute of Chemistry, State University of Campinas, UNICAMP, P.O. Box 6154, 13083-970 Campinas-SP, Brazil \\ ${ }^{b}$ Materials Chemistry Department, V.N. Karazin Kharkiv National University, 4 Svoboda Square, \\ Kharkiv, 61077, Ukraine
}

\begin{abstract}
Os polímeros $\mathrm{Si}_{3} \mathrm{Py}^{+} \mathrm{Cl}^{-}(\mathrm{A})$ e $\mathrm{Si} 4 \mathrm{Py}^{+} \mathrm{Cl}^{-}(\mathrm{B})$, cloretos de 3-n-propil(3-metilpiridínio) silsesquioxano e 3- $n$-propil(4-metilpiridínio)silsesquioxano respectivamente, foram preparados pelo método de síntese sol-gel. Os valores de capacidade de troca iônica $\left(\mathrm{mmol} \mathrm{g}^{-1}\right)$ foram iguais a $0,90 \mathrm{e}$ 0,81 para (A) e (B), respectivamente. Considerando a reação $\mathrm{nSiPy}^{+} \mathrm{Cl}_{(\mathrm{s})}^{-}+\mathrm{M}^{2+}{ }_{(\mathrm{s} n)}+2 \mathrm{Cl}_{(\mathrm{sln})}^{-}=$ $\left(\mathrm{SiPy}^{+}\right)_{\mathrm{n}} \mathrm{MCl}_{2+\mathrm{n}^{\mathrm{n}}{ }^{\mathrm{n}} \mathrm{s}}$, as constantes de equilíbrio calculadas para cada etapa foram: $(\mathrm{A}): \mathrm{Cu}^{\mathrm{II}}, \log \mathrm{K}_{(2)}{ }^{1}=$ $4,14(0,03), \log \mathrm{K}_{(2)}{ }^{2}=2,91(0,04) ; \mathrm{Zn}^{\text {II }}, \log \mathrm{K}_{(2)}{ }^{1}=3,3(0,3), \log \mathrm{K}_{(2)}{ }^{2}=4,9(0,3) ;(\mathrm{B}): \mathrm{Cu}^{\mathrm{II}}, \log \mathrm{K}_{(2)}{ }^{1}=$ $3,82(0,03), \log \mathrm{K}_{(2)}{ }^{2}=3,00(0,04) ; \mathrm{Zn}^{\mathrm{II}}, \log \mathrm{K}_{(2)}{ }^{1}=3,93(0,03), \log \mathrm{K}_{(2)}{ }^{2}=3,55(0,08)$, onde $\mathrm{K}_{(2)}{ }^{1} \mathrm{e} \mathrm{K}_{(2)}{ }^{2}$ correspondem às constantes de equilíbrio de adsorção das espécies $\mathrm{MCl}_{4}{ }^{2-} \mathrm{e}^{-} \mathrm{MCl}_{3}{ }^{-}$, respectivamente. No caso da adsorção de $\mathrm{Zn}^{\mathrm{II}}$ sobre $\mathrm{Si} 3 \mathrm{Py}^{+} \mathrm{Cl}^{-}$, em que $\mathrm{K}_{(2)}{ }^{2}>\mathrm{K}_{(2)}{ }^{1}$, uma cooperatividade positiva é observada, ou seja, a adsorção da espécie $\mathrm{MCl}_{4}{ }^{2-}$ facilita a adsorção da espécie $\mathrm{MCl}_{3}^{-}$. Nos demais casos, $\mathrm{K}_{(2)}{ }^{1}>\mathrm{K}_{(2)}{ }^{2}$, o que indica que a adsorção da espécie $\mathrm{MCl}_{4}{ }^{2-}$ dificulta a adsorção da espécie $\mathrm{MCl}_{3}^{-}$na superfície dos adsorventes, indicando uma cooperatividade negativa.
\end{abstract}

Polymers $\mathrm{Si}_{3} \mathrm{Py}^{+} \mathrm{Cl}^{-}(\mathrm{A})$ and $\mathrm{Si} 4 \mathrm{Py}^{+} \mathrm{Cl}^{-}(\mathrm{B}), 3-n$-propyl(3-methylpyridinium)silsesquioxane and 3- $n$-propyl(4-methylpyridinium)silsesquioxane chlorides, respectively, were prepared by the sol-gel processing method. The ion exchange capacities $\left(\mathrm{mmol} \mathrm{g}^{-1}\right)$ were 0.90 and 0.81 for $(\mathrm{A})$ and $(\mathrm{B})$ respectively. Considering the reaction $\mathrm{nSiPy}^{+} \mathrm{Cl}_{(\mathrm{s})}^{-}+\mathrm{M}^{2+}{ }_{(\mathrm{s})}+2 \mathrm{Cl}_{(\mathrm{s}) \mathrm{n})}^{-} \rightleftharpoons\left(\mathrm{SiPy}^{+}\right)_{\mathrm{n}} \mathrm{MCl}_{2+\mathrm{n}}^{\mathrm{n}-}{ }_{(\mathrm{s})}$, the values of the stepwise equilibrium constants obtained were: (A) $\mathrm{Cu}^{\mathrm{II}}: \log \mathrm{K}_{(2)}{ }^{1}=4.14(0.03)$, $\log \mathrm{K}_{(2)}{ }^{2}=2.91(0.04) ; \mathrm{Zn}^{\text {II }}, \log \mathrm{K}_{(2)}{ }^{1}=3.3(0.3), \log \mathrm{K}_{(2)}{ }^{2}=4.9(0.3) ;(\mathrm{B}) \mathrm{Cu}^{\mathrm{II}}: \log \mathrm{K}_{(2)}{ }^{1}=3.82(0.03)$, $\log \mathrm{K}_{(2)}{ }^{2}=3.00(0.04) ; \mathrm{Zn}^{\text {II }}, \log \mathrm{K}_{(2)}{ }^{1}=3.93(0.03), \log \mathrm{K}_{(2)}{ }^{2}=3.55(0.08)$, being $\mathrm{K}_{(2)}{ }^{1}$ and $\mathrm{K}_{(2)}{ }^{2}$ the equilibrium constants for adsorption of the species $\mathrm{MCl}_{4}^{2-}$ and $\mathrm{MCl}_{3}^{-}$, respectively. For adsorption of $\mathrm{Zn}^{\mathrm{II}}$ on $\mathrm{Si}_{3} \mathrm{Py}^{+} \mathrm{Cl}^{-}, \mathrm{K}_{(2)}{ }^{2}>\mathrm{K}_{(2)}{ }^{1}$, indicating positive cooperativity, i.e., the adsorption of $\mathrm{MCl}_{4}{ }^{2-}$ enhances the adsorption of $\mathrm{MCl}_{3}{ }^{-}$species on the adsorbent surface. For the other cations, $\mathrm{K}_{(2)}{ }^{1}>\mathrm{K}_{(2)}{ }^{2}$, indicating that adsorption of $\mathrm{MCl}_{4}{ }^{2-}$ depresses the adsorption of $\mathrm{MCl}_{3}{ }^{-}$species, indicating negative cooperativity.

Keywords: methylpyridinium, silsesquioxane modified polymer, adsorption, stability constants at heterogeneous surface, solid-solution interface

\section{Introduction}

In recent years the use of solids, modified or not with functional groups, presenting affinities towards several metal ions in solution phase has been reported. A large variety of materials such as zeolite, alumina and silica have been commonly used in metal adsorption processes. Other materials such as activated carbon, fly ash and red mud, calcium hydroxyapatite and modified amberlite have also been used in preconcentration and separation processes. ${ }^{1-7}$

*e-mail: gushikem@iqm.unicamp.br
Organofunctionalized silica has been the subject of large interest due to its multiple use in high-efficiency liquid chromatography, in preconcentration and separation processes by ion exchange reactions and as substrate base to produce electrochemical sensors. ${ }^{8-14}$ Modified silica is usually obtained by immobilizing an organofunctional group, presenting a Lewis basic group, on a porous silica surface by the grafting reaction process. ${ }^{15-17}$ On non porous substrates, the grafting of organofunctional groups has been achieved after covering the surface with a thin layer film of metal oxides. ${ }^{18-20}$ However, as these methods are time consuming procedures, in the last decade a new class of 
organofunctionalized materials has been obtained by using the sol-gel processing method. This method is based on polycondensation reactions of functionalized alkoxysilane in the presence of tetralkylorthosilicate, in order to obtain a chemically modified silsesquioxane polymer. ${ }^{21-25}$ Prepared hybrid xerogels, in almost all solids obtained, present homogeneous distribution of the organic groups throughout the matrix volume. They have shown to be very promising as high capacity and efficient adsorbent materials. ${ }^{26-29}$

Despite the several works on the use of these modified solids reported in the literature, a better understanding of the adsorption mechanism on the surface of these solids is necessary. Normally, the model used has been the ideal process where interactions between the adsorbed species on the surfaces are neglected..$^{30,31}$ Only in recent years the quantification and the mechanism of adsorption on these heterogeneous surfaces have been subject of detailed study. ${ }^{32-34}$ Methods based on this model of non ideal character have enabled the determination of stoichiometric composition and affinity constants of the species in equilibrium at the solid-solution interface. ${ }^{35}$

The present work describes two new hybrid materials obtained by sol-gel synthesis, denominated as 3- $n$-propyl(3-methylpyridinium) silsesquioxane chloride $\left(\mathrm{Si}^{3} \mathrm{Py}^{+} \mathrm{Cl}^{-}\right)$ and 3-n-propyl-(4-methylpyridinium) silsesquioxane chloride $\left(\mathrm{Si}_{4} \mathrm{Py}^{+} \mathrm{Cl}^{-}\right)$, aiming at their use as adsorbent materials. They were applied in the adsorption processes of $\mathrm{Cu}^{\mathrm{II}}$ and $\mathrm{Zn}^{\mathrm{II}}$ from ethanol solution. The mechanism of interaction between the adsorbed species on the solid surface is discussed in detail.

\section{Experimental}

\section{Preparation of $\mathrm{Si}_{3} \mathrm{Py}^{+} \mathrm{Cl}^{-}$and $\mathrm{Si} 4 \mathrm{Py}^{+} \mathrm{Cl}^{-}$}

The materials were prepared according to a previously described method. ${ }^{36}$ The idealized structure of the ion exchanger polymers $\mathrm{Si} 3 \mathrm{Py}^{+} \mathrm{Cl}^{-}$and $\mathrm{Si} 4 \mathrm{Py}^{+} \mathrm{Cl}^{-}$is shown in Figure 1.

Briefly, tetraethylorthosilicate (TEOS), ethanol and aqueous $\mathrm{HCl}$ solution were mixed in a round bottomed flask, and the resulting solution was stirred for $2.5 \mathrm{~h}$ at room temperature (298 K, step (a) in Figure 1). To this solution 3-n-chloropropyltrimethoxysilane, CPTS, was added, and the solution stirred for $2 \mathrm{~h}$ at room temperature (step (b)). The temperature of the solution was raised to $328 \mathrm{~K}$ and the mixture was allowed to stand for $60 \mathrm{~h}$ open to the ambient atmosphere until the gelation process occurred. The resulting gel was powdered, washed with ethanol and then dried under vacuum $\left(133 \times 10^{-3} \mathrm{~Pa}\right)$ at room temperature. The dry gel was immersed in a round
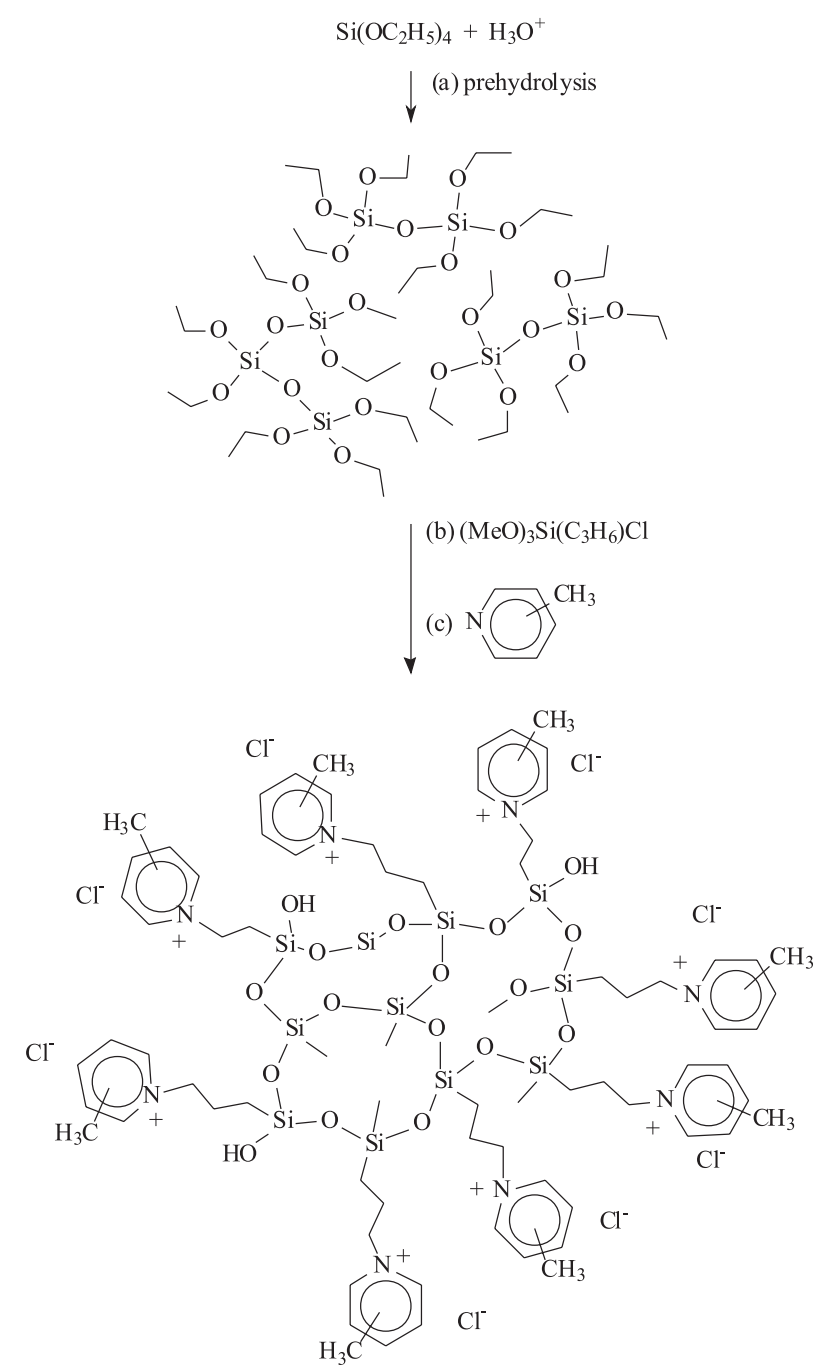

Figure 1. Fluxogram of the preparation of $\mathrm{SiPy}^{+} \mathrm{Cl}^{-}$by the sol-gel method.

bottomed flask containing a solution prepared by mixing pure 3-methylpyridine or 4-methylpyridine and dry toluene (step (c)). Each mixture was heated at the reflux temperature of the solvent for approximately $3 \mathrm{~h}$. The solids were filtered, washed with ethanol and dried for $2 \mathrm{~h}$ under vacuum $\left(133 \times 10^{-3} \mathrm{~Pa}\right)$ at room temperature.

\section{Chemical analyses}

The elemental analyses were carried out on a PerkinElmer model $2400 \mathrm{CHN}$ analyzer. Triplicate measurements were made for each sample.

To determine the concentration of exchangeable chloride ions, approximately $0.050 \mathrm{~g}$ of material was immersed into $30 \mathrm{~mL}$ of $0.1 \mathrm{~mol} \mathrm{~L}{ }^{-1} \mathrm{HNO}_{3}$ aqueous solution. The chloride ions released to the solution phase were titrated with standard $0.01 \mathrm{~mol} \mathrm{~L}^{-1} \mathrm{AgNO}_{3}$ solution, using the potentiometric titration method. 


\section{Physical measurements}

The CP-MAS ${ }^{13} \mathrm{C}$ NMR spectra of the samples were obtained on a Bruker AC 300P spectrometer. A pulse sequence with contact time of $1 \mathrm{~ms}$, interval between pulses of $2 \mathrm{~s}$ and acquisition time of $133 \mathrm{~ms}$ was used.

The thermogravimetric analyses were made on a Dupont TGA 2050 apparatus. About $10 \mathrm{mg}$ of each material was heated with a heating rate of $10 \mathrm{~K} \mathrm{~min}^{-1}$ in the temperature range between 298 and $1243 \mathrm{~K}$, under nitrogen atmosphere.

\section{$\mathrm{MCl}_{2}$ adsorption isotherms}

The adsorption of $\mathrm{CuCl}_{2}$ and $\mathrm{ZnCl}_{2}$ from ethanol solutions by $\mathrm{Si} 3 \mathrm{Py}^{+} \mathrm{Cl}^{-}$and $\mathrm{Si} 4 \mathrm{Py}^{+} \mathrm{Cl}^{-}$was studied at $298 \mathrm{~K}$ by the batch technique. Solutions $(50 \mathrm{~mL})$ containing variable concentrations of the metal and about $50 \mathrm{mg}$ of the adsorbent solid were shaken for $3 \mathrm{~h}$ at $298 \mathrm{~K}$. The amount of metal ion adsorbed by the solid phase was calculated by applying the equation:

$\mathrm{N}_{\mathrm{f}}=\left(\mathrm{N}_{\mathrm{i}}-\mathrm{N}_{\mathrm{s}}\right) / \mathrm{m}$

where $\mathrm{N}_{\mathrm{i}}$ is the initial mole number of metal added, $\mathrm{N}_{\mathrm{s}}$ is the mole number of the metal in the solution phase in equilibrium with the solid phase, and $\mathrm{m}$ is the mass of the solid phase. $\mathrm{N}_{\mathrm{s}}$ was determined by complexometric titration using $0.01 \mathrm{~mol} \mathrm{~L}^{-1}$ standard edta solution.

\section{Results and Discussion}

\section{Characteristics of the material}

The results of elemental analyses and determination of exchangeable chloride ions in $\mathrm{SiPy}^{+} \mathrm{Cl}^{-}$are summarized in Table 1.
Table 1. Results of elemental analyses $(\mathrm{C}, \mathrm{H}, \mathrm{N})$ and determination of ionized chloride $\left(\mathrm{Cl}^{-}\right)$

\begin{tabular}{lcccc}
\hline Material & $\mathrm{C} / \mathrm{wt} \%$ & $\mathrm{H} / \mathrm{wt} \%$ & $\mathrm{~N} / \mathrm{wt} \%$ & $\mathrm{Cl}^{-} / \mathrm{mmol} \mathrm{g}^{-1}$ \\
\hline $\mathrm{Si} \mathrm{Py}^{+} \mathrm{Cl}^{-}$ & 21.0 & 4.4 & 1.36 & 0.90 \\
$\mathrm{Si}^{-} \mathrm{Py}^{+} \mathrm{Cl}^{-}$ & 22.0 & 4.2 & 1.11 & 0.80 \\
\hline
\end{tabular}

The results for $\mathrm{N}$ and $\mathrm{Cl}^{-}$contents indicate that the materials were prepared with good yield (practically 100\%), i.e., in step (c) of Figure 1, practically all metylpyridine reacted with the chloropropyl pendant groups. The molar ratios $\mathrm{N} / \mathrm{Cl}^{-}$obtained from experimental data are 1.07 and 0.99 for $\mathrm{Si}_{3} \mathrm{Py}^{+} \mathrm{Cl}^{-}$and $\mathrm{Si} 4 \mathrm{Py}^{+} \mathrm{Cl}^{-}$, respectively.

The ${ }^{13} \mathrm{C}$ NMR spectral data for $\mathrm{Si}_{3} \mathrm{Py}^{+} \mathrm{Cl}^{-}$(a) and for $\mathrm{Si} 4 \mathrm{Py}^{+} \mathrm{Cl}^{-}$(b) are summarized on Table 2. The chemical shifts observed fit those reported for similar materials. ${ }^{37-42}$

Infrared spectra of both samples showed two medium intensity absorption bands at 1635 and $1511 \mathrm{~cm}^{-1}\left(\mathrm{Si} 3 \mathrm{Py}^{+} \mathrm{Cl}^{-}\right)$ and at 1636 and $1447 \mathrm{~cm}^{-1}\left(\mathrm{Si} 4 \mathrm{Py}^{+} \mathrm{Cl}^{-}\right)$, assigned respectively to the ring coupled stretching vibration $(\mathrm{vCC}+\mathrm{vCN})$ and the deformation mode of the methyl group $\left(\mathrm{\delta CH}_{3}\right)$ of the pyridinium group attached to the silsesquioxane framework (IR spectra are not shown). ${ }^{43}$

The results of thermogravimetric analyses (Figure 2) show that the materials are stable up to $522 \mathrm{~K}$, decomposing above this temperature with loss of methyl pyridine molecules.

\section{Adsorption isotherms}

Figure 3 shows the adsorption isotherms for $\mathrm{CuCl}_{2}$ and $\mathrm{ZnCl}_{2}$ on $\mathrm{Si}_{3} \mathrm{Py}^{+} \mathrm{Cl}^{-}$and $\mathrm{Si} 4 \mathrm{Py}^{+} \mathrm{Cl}^{-}$, obtained from ethanol solutions, at $298 \mathrm{~K}$.

The adsorption process occurs according to the equilibrium reaction described by equation (1). The metal

Table 2. CP-MAS ${ }^{13} \mathrm{C}$ NMR data for 3- $n$-propyl(3-methylpyridinium)silsesquioxane and for 3- $n$-propyl(4-methylpyridinium)silsesquioxane chlorides

\begin{tabular}{|c|c|c|c|}
\hline$-\stackrel{\mathrm{Si}-}{\mathrm{l}}$ & $\int_{3}^{7} 6 \mathrm{Cl}^{-}$ & $-{ }_{\mathrm{Si}}$ & $-\stackrel{7}{\mathrm{CH}_{3} \quad \mathrm{Cl}^{-}}$ \\
\hline$\delta / \mathrm{ppm}^{*}$ & Assignments & $\delta / \mathrm{ppm}$ & Assignments \\
\hline 11.2 & $\mathrm{C}_{1}$ & 11.2 & $\mathrm{C}_{1}$ \\
\hline 27.7 & $\mathrm{C}_{2}$ & 27.7 & $\mathrm{C}_{2}$ \\
\hline 48.4 & $\mathrm{C}_{3}$ & 48.6 & $\mathrm{C}_{3}$ \\
\hline $123-132$ & $\mathrm{C}_{5}, \mathrm{C}_{8}$ & 129.0 & $\mathrm{C}_{5}$ \\
\hline $135-150$ & $\mathrm{C}_{4}, \mathrm{C}_{6}, \mathrm{C}_{9}$ & 145.0 & $\mathrm{C}_{4}, \mathrm{C}_{6}$ \\
\hline 19.9 & $\mathrm{C}_{7}$ & 23.2 & $\mathrm{C}_{7}$ \\
\hline
\end{tabular}

*chemical shift 


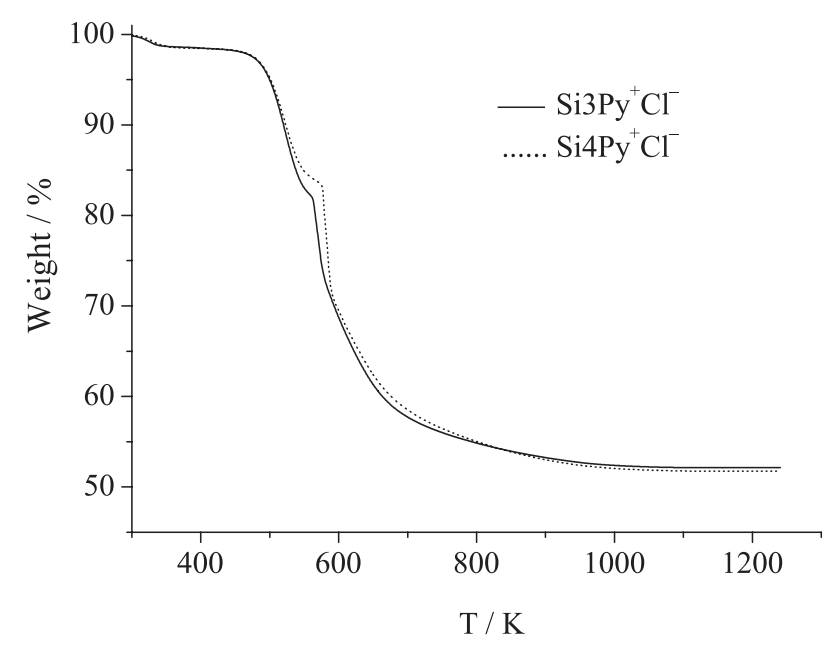

Figure 2. Thermogravimetric analyses of the materials: (a) $\mathrm{Si}_{3} \mathrm{Py}^{+} \mathrm{Cl}^{-}$and (b) $\mathrm{Si} 4 \mathrm{Py}^{+} \mathrm{Cl}^{-}$.
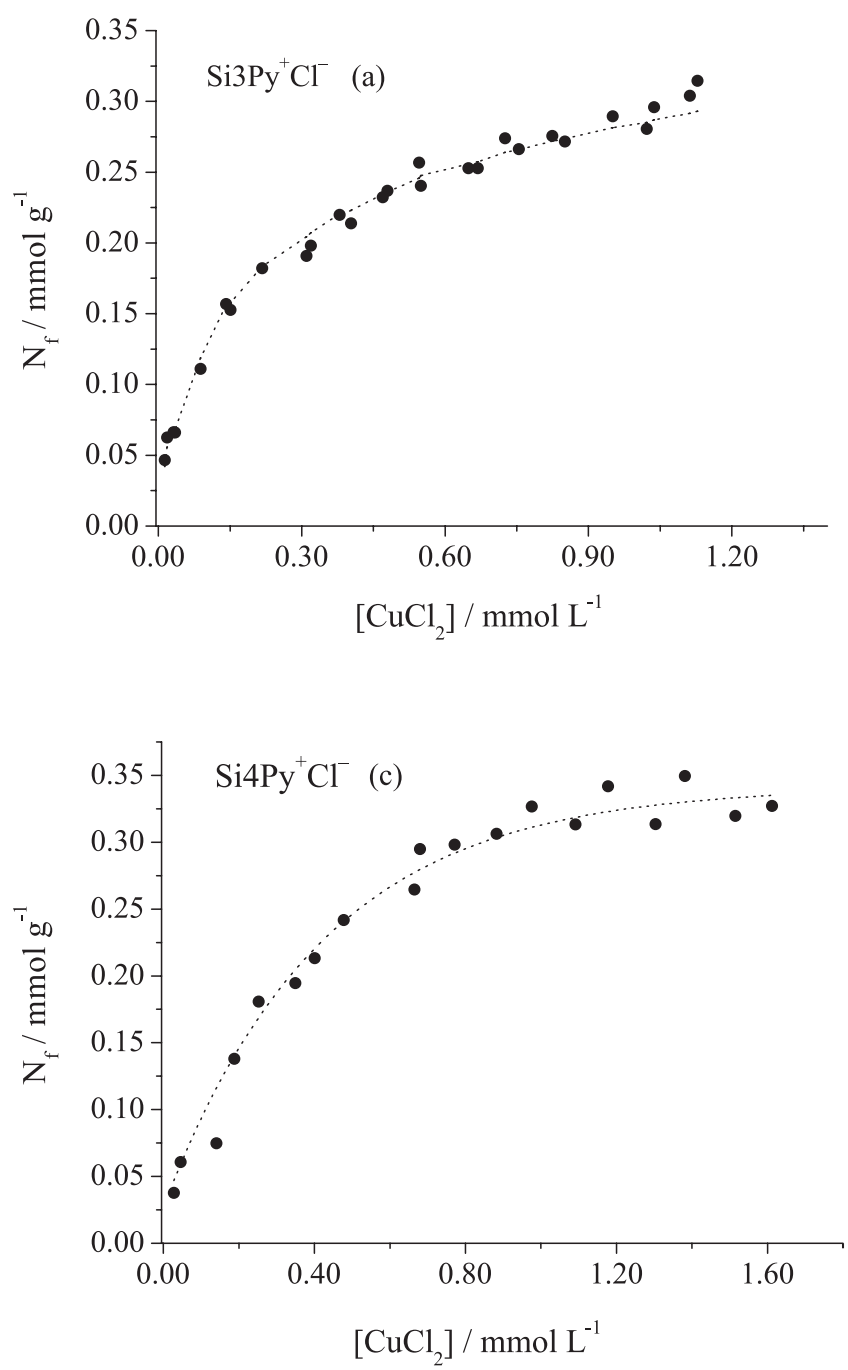

ion diffuses into the solid-solution interface followed by the counterion $\mathrm{Cl}^{-}$, forming the $\mathrm{MCl}_{2+\mathrm{n}}{ }^{\mathrm{n}-}$ complex on the surface, in order to keep the electroneutrality:

$\mathrm{nSiPy}^{+} \mathrm{Cl}_{(\mathrm{s})}^{-}+\mathrm{M}^{2+}{ }_{(\mathrm{sln})}+2 \mathrm{Cl}_{(\mathrm{sln})} \rightleftharpoons\left(\mathrm{SiPy}^{+}\right)_{\mathrm{n}} \mathrm{MCl}_{2+\mathrm{n}}{ }^{\mathrm{n}-}{ }_{(\mathrm{s})}$

where $\mathrm{SiPy}^{+} \mathrm{Cl}^{-}$represents the 3-n-propyl(3-methylpyridinium) or 3-n-propyl(4-methylpyridinium) chloride pendant functional groups attached to the silica framework, $\mathrm{n}$ is number of the pendant groups in the reaction site and (s) and $(\sin )$ are the solid and solution phases, respectively. If $\mathrm{n}>1$, the pendant functional groups act as a set of spatially oriented polydentate cationic ligands. The dissociation and autocomplexation of $\mathrm{MCl}_{2}$ in solution phase can be neglected, since they do not distort the main conclusions about the adsorption processes. ${ }^{44}$
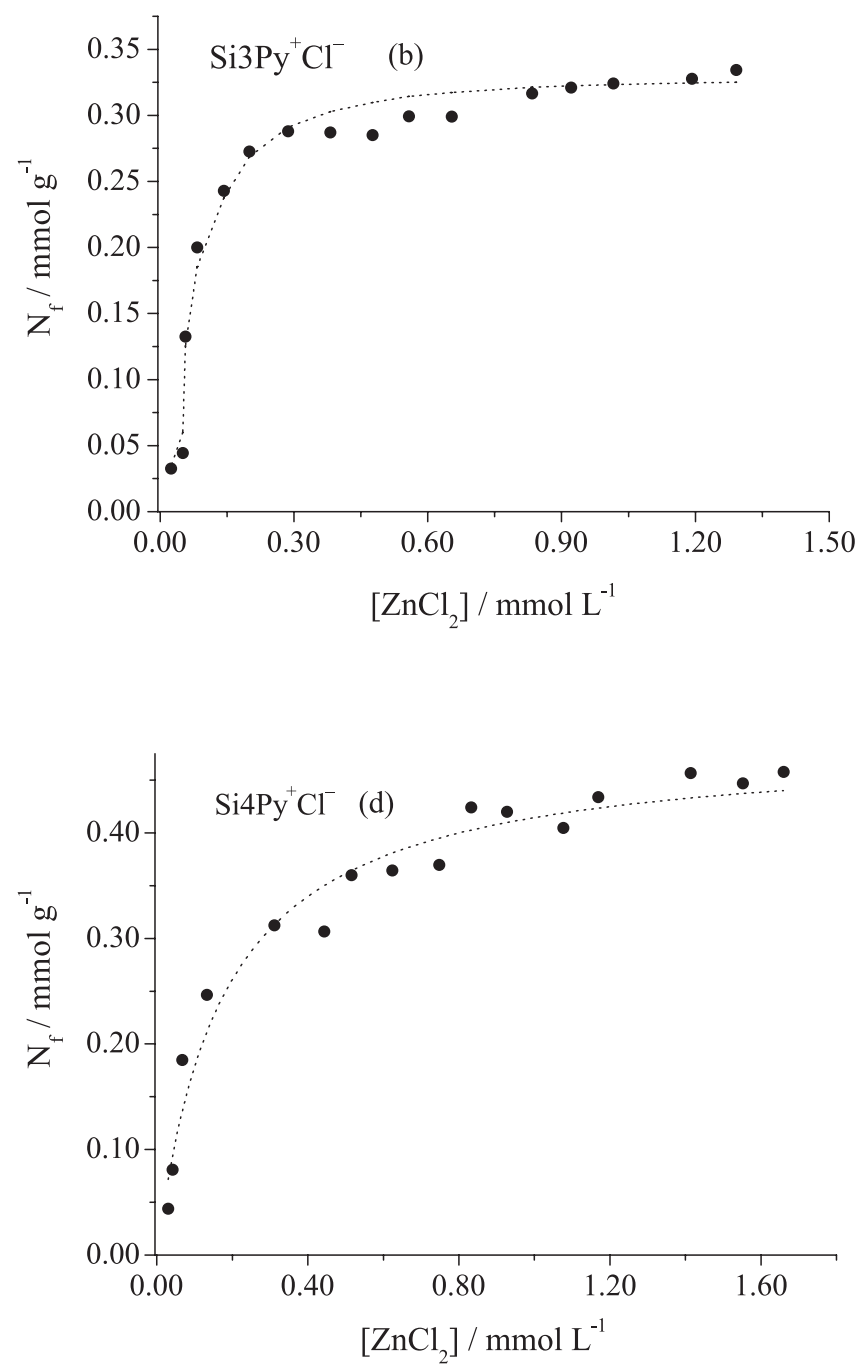

Figure 3. Adsorption isotherms of $\mathrm{MCl}_{2}$ from ethanol solutions at $298 \mathrm{~K}$ : (a) $\mathrm{CuCl}_{2}$ and (b) $\mathrm{ZnCl}_{2}$ on $\mathrm{Si}_{3} \mathrm{Py}^{+} \mathrm{Cl}^{-}$; (c) $\mathrm{CuCl}_{2}$ and (d) $\mathrm{ZnCl}_{2}$ on $\mathrm{Si} 4 \mathrm{Py}{ }^{+} \mathrm{Cl}$. ( experimental data, (---) calculated values by the bidentate binding model. 

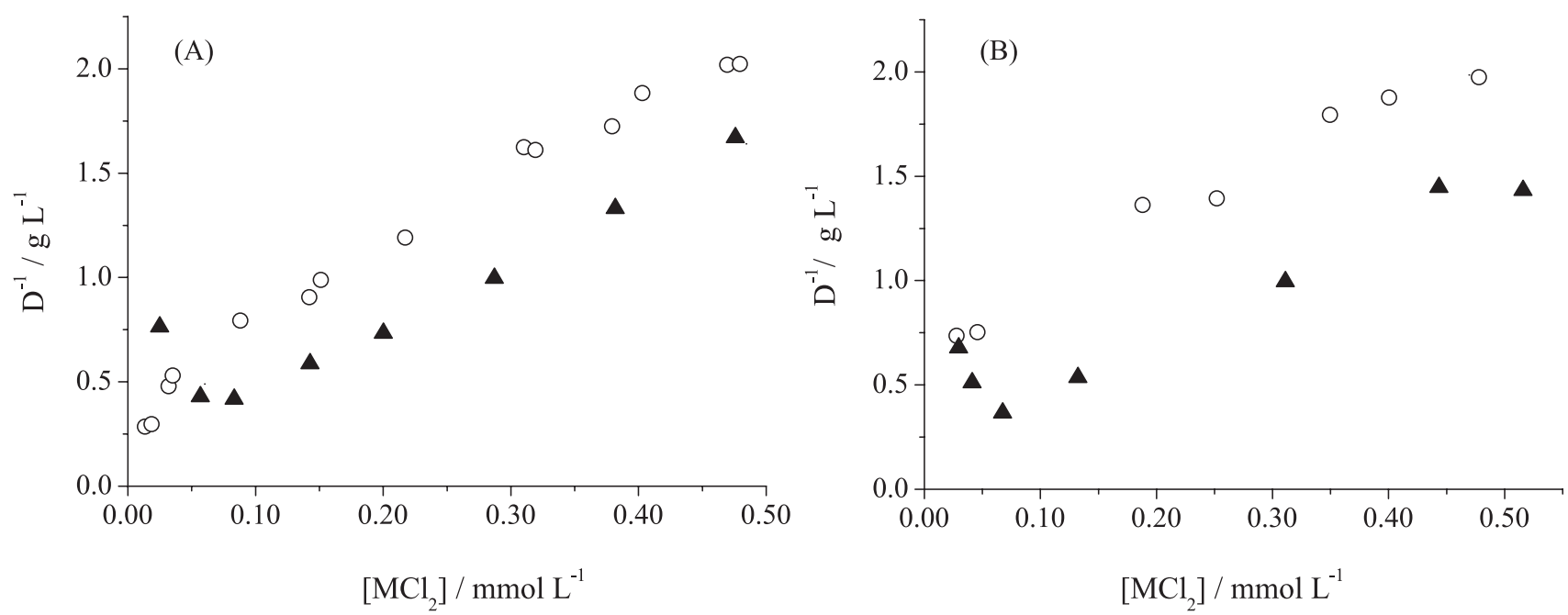

Figure 4. Plots of $\mathrm{D}^{-1}$ versus $\left[\mathrm{MCl}_{2}\right]$ on $\mathrm{Si}_{3} \mathrm{Py}^{+} \mathrm{Cl}^{-}(\mathrm{A})$ and $\mathrm{Si}_{4} \mathrm{Py}^{+} \mathrm{Cl}^{-}(\mathrm{B})$ in ethanol solution. $(\mathrm{O}) \mathrm{CuCl}_{2},(\boldsymbol{\Delta}) \mathrm{ZnCl}_{2}$.

To describe quantitatively the adsorption equilibrium, one has to estimate the adsorption capacity of the material, $\mathrm{t}_{\mathrm{Q}}\left(\right.$ in $\mathrm{mol} \mathrm{g}^{-1}$ ), in respect to $\mathrm{MCl}_{2}$ and constants of adsorption equilibria. The concentration of active binding groups ("effective capacity") may differ significantly from the experimental capacity found by elemental analyses of $\mathrm{N}_{\mathrm{f}}$ or from the ion exchange capacities determined by the ionized chloride. It depends on the stoichiometry of interactions of $\mathrm{MCl}_{2}$ with the active surface groups $\mathrm{SiPy}^{+} \mathrm{Cl}^{-}$, accessibility to sorption centers, their affinity by metal chlorides, nature of solvent and other factors. Therefore, this quantity should be determined together with the composition of surface complexes and their thermodynamic stability. All these tasks are solved by means of application of meaningful models for describing experimental adsorption isotherms.

In the simplest case, adsorption of metal chlorides may be described as a reaction between a sorbate entity $\mathrm{S}$ and an active sorption center:

$\overline{\mathrm{Q}}+\mathrm{S} \stackrel{\mathrm{SQ}}{\leftarrow} \quad \beta$

where $\mathrm{S}$ is $\mathrm{MCl}_{2(\text { snn })}, \overline{\mathrm{Q}}$ is the fixed active center $\left(\mathrm{SiPy}^{+} \mathrm{Cl}_{(\mathrm{s})}^{-}\right)$, $\overline{\mathrm{SQ}}\left(\left(\mathrm{SiPy}^{+}\right)_{\mathrm{n}} \mathrm{MCl}_{2+\mathrm{n}(\mathrm{s})}^{\mathrm{n}-}\right)$ is the surface complex, and $\beta$ is the heterogeneous global or overall stability constant. When complexes $\overline{\mathrm{SQ}}$ of only one type are formed, all sorption centers $\bar{Q}$ are energetically homogeneous and lateral interactions are absent, the sorption is of ideal character and can be described by the Langmuir equation in the linear form, represented by equation 3 :

$\mathrm{D}^{-1}=\frac{[\mathrm{S}]}{[\overline{\mathrm{SQ}}]}=\frac{1}{\beta \mathrm{t}_{\mathrm{Q}}}+\frac{[\mathrm{S}]}{\mathrm{t}_{\mathrm{Q}}}$

where $[\overline{\mathrm{SQ}}]$ is the specific concentration of adsorbed species $\mathrm{S}$ (in $\left.\mathrm{mol} \mathrm{g}^{-1}\right),[\mathrm{S}]$ is the equilibrium concentration $\left(\mathrm{mol} \mathrm{L}^{-1}\right)$, $\mathrm{D}^{-1}$ is the reciprocal of the distribution coefficient (in $\mathrm{g} \mathrm{L}^{-1}$ ).
If the plot of $\mathrm{D}^{-1}$ versus $[\mathrm{S}]$ is linear, the model of ideal sorption is considered to be valid. ${ }^{45}$ The values of unknown parameters of the model, $\mathrm{t}_{\mathrm{Q}}$ and $\beta$, are calculated from the coefficients of a linear $\mathrm{D}^{-1}$ versus $[\mathrm{S}]$ dependence.

Unfortunately, this simple model did not fit properly the experimental adsorption isotherms of $\mathrm{MCl}_{2}$. At the lower $\mathrm{CuCl}_{2}$ and $\mathrm{ZnCl}_{2}$ concentrations, deviation of the experimental $\mathrm{D}^{-1}$ values from the straight lines is observed (Figure 4), pointing to the non-ideal character of the adsorption process.

This non-ideal character of adsorption was interpreted in terms of the cooperativity effect, which will be discussed in detail at the end of this section. The affinity of the $\mathrm{MCl}_{2+\mathrm{n}}{ }^{\mathrm{n}}$ for the cationic pendant groups may be enhanced (positive cooperativity) or depressed (negative cooperativity) by a previous occupation of the site by a metal complex. ${ }^{46}$ The description of the non-ideality in terms of cooperativity effects was performed with the aid of the model of polidentate binding. ${ }^{47}$ According to it, the surface of a sorbent is considered as an assemblage of independent centers containing several $\mathrm{SiPy}^{+}$cations and the respective number of $\mathrm{Cl}^{-}$ions as counterions. The simplest version, the model of bidentate binding, represents the adsorption process by the following equilibrium reactions:

$\underset{-\mathrm{Py}^{+} \mathrm{Cl}^{-}}{\mathrm{Py}^{+} \mathrm{Cl}^{-}}+\mathrm{M}^{2+}+2 \mathrm{Cl}^{-} \stackrel{\beta_{(2)}{ }^{1} \rightleftharpoons}{\rightleftharpoons}{ }_{\mathrm{Py}^{+}}^{-\mathrm{Py}^{+}}{ }^{\left[\mathrm{MCl}_{4}\right]^{2-}}$

$\left(\mathrm{S}_{1}\right)$

$\sum_{\mathrm{Py}^{+} \mathrm{Cl}^{-}}^{\mathrm{Py}^{+} \mathrm{Cl}^{-}}+2 \mathrm{M}^{2+}+4 \mathrm{Cr} \stackrel{\beta_{(2)}{ }^{2}}{\rightleftharpoons} \underset{-\mathrm{Py}^{+}\left[\mathrm{MCl}_{3}\right]^{-}}{\mathrm{Py}^{+}\left[\mathrm{MCl}_{3}\right]^{-}}$

$\left(\mathrm{S}_{3}\right)$

where $\mathrm{M}=\mathrm{Cu}^{\mathrm{II}}$ or $\mathrm{Zn}^{\mathrm{II}}, \beta_{(2)}^{1}$ and $\beta_{(2)}^{2}$ are the global or overall stability constants: 
$\beta_{(2)}{ }^{1}=\frac{\left.\left\{\begin{array}{l}-\mathrm{Py}^{+} \\ -\mathrm{Py}^{+}\end{array} \mathrm{MCl}_{4}\right]^{2-}\right\}}{\left\{\begin{array}{l}\mathrm{Py}^{+} \mathrm{Cl} \\ -\mathrm{Py}^{+} \mathrm{Cl}^{-}\end{array}\right\}\left[\mathrm{MCl}_{2}\right]}$

and

$\left.\beta_{(2)}\right)^{2}=\frac{\left\{\begin{array}{l}-\mathrm{Py}^{+}\left[\mathrm{MCl}_{3}\right]^{-} \\ -\mathrm{Py}^{+}\left[\mathrm{MCl}_{3}\right]^{-}\end{array}\right\}}{\left\{\begin{array}{l}-\mathrm{Py}^{+} \mathrm{Cl}{ }^{-} \\ -\mathrm{Py}^{+} \mathrm{Cl}^{-}\end{array}\right\}\left[\mathrm{MCl}_{2}\right]^{2}}$

where \{\} and [ ] indicate the concentrations in solid and solution phases.

The relation between $\beta_{(2)}{ }^{1}$ and $\beta_{(2)}{ }^{2}$ is $\beta_{(2)}{ }^{2}=\mathrm{K}_{(2)}{ }^{1} \mathrm{~K}_{(2)}{ }^{2}$ and $\beta_{(2)}{ }^{1} \equiv \mathrm{K}_{(2)}{ }^{1}$, where $\mathrm{K}_{(2)}{ }^{\mathrm{i}}$ are the stepwise stability constants. $\mathrm{K}_{(2)}{ }^{2}$ is defined as:

$\mathrm{K}_{(2)}^{2}=\frac{\left\{\begin{array}{c}\mathrm{Py}^{+}\left[\mathrm{MCl}_{3}\right] \\ -\mathrm{Py}^{+}\left[\mathrm{MCl}_{3}\right]^{-}\end{array}\right\}}{\left\{\mathrm{Py}^{+} \mathrm{MCl}_{4}^{2-}\right\}\left[\mathrm{MCl}_{2}\right]}$

In the equations, the subscript corresponds to the number of functional groups $-\mathrm{Py}^{+} \mathrm{Cl}^{-}$included into one sorption center (in the present case, two sorption sites in each center) and the superscript is the order of the constant, i.e., the number of $\mathrm{MCl}_{2}$ entities attached to a sorption center. In equation (1) we observe that $\mathrm{M}^{2+}$ and $\mathrm{Cl}^{-}$ dissociated species are adsorbed as neutral species $\mathrm{MCl}_{2}$, since in the diffusion process of $\mathrm{M}^{\mathrm{II}}$ into the solid-solution interface it is followed by the counterions.

The occupation of all sorption centers with $\mathrm{MCl}_{2}$ was not achieved in any case even at the highest $\mathrm{MCl}_{2}$ concentration studied. Because of this, the maximum reached $\mathrm{N}_{\mathrm{f}}$ values gave only rough estimations of the adsorption capacity, $\mathrm{t}_{\mathrm{Q}}$. Therefore, it was necessary to estimate simultaneously all fitting parameters of the model, i.e., $\mathrm{t}_{\mathrm{Q}}, \beta_{(2)}{ }^{1}$ and $\beta_{(2)}{ }^{2}$.

The possible values of sorption capacities $t_{Q}$ were scanned, and for each tested $t_{Q}$ value, the values of fitting parameters $\beta_{(2)}{ }^{1}$ and $\beta_{(2)}{ }^{2}$ were calculated through minimization of the criterion:

$\chi_{\exp }^{2}=\sum_{\mathrm{k}=1}^{\mathrm{n}} \mathrm{w}_{\mathrm{k}} \Delta_{\mathrm{k}}^{\mathrm{n}}$

where $k$ is the $k^{\text {th }}$ experimental points, $\Delta=\mathrm{N}_{\mathrm{f}}^{\text {calc }}-\mathrm{N}_{\mathrm{f}}^{\text {exp }}$, and $\mathrm{w}_{\mathrm{k}}$ is the statistical weight assigned as

$\mathrm{w}_{\mathrm{k}}=\frac{1}{\mathrm{~N}_{\mathrm{f}}^{2} \sigma_{\mathrm{r}}}$ with $\sigma_{\mathrm{r}}=0.05(5 \%)$ as the relative random error in the $\mathrm{N}_{\mathrm{f}}$ determination. The global criterion $\chi^{2}$ was applied to test the statistical adequacy of the models. The models were assumed to be adequate if the following inequality was fulfilled:

$\chi_{\exp }^{2}<\chi_{f}^{2}(5 \%)$,

where $\chi^{2}(5 \%)$ is the $5 \%$ point of the chi-squared distribution with $\mathrm{f}$ degrees of freedom $(\mathrm{f}=\mathrm{N}-\mathrm{Z}$, where $\mathrm{Z}$ is the number of unknown equilibrium constants and $\mathrm{N}$ is the total number of experimental points). The $\mathrm{t}_{\mathrm{Q}}$ value (and the corresponding values of equilibria constants), which resulted in the minimum value of $\chi_{\text {exp }}^{2}$, was accepted as the most trustworthy estimations that provided the best fit of the measured sorption isotherm. All calculations for the model of bidentate binding were performed with the aid of the CLINP 2.1 software program. ${ }^{48,49}$ The results of simulations are summarized in Table 3 . The calculated isotherms (dotted lines) are shown in Figure 3.

In order to have a better understanding of the adsorption mechanism, and taking into account that all stepwise constants were calculated, the distribution coefficients, $\alpha_{i}$, were determined for $S_{1}, S_{2}$ and $S_{3}$ species by applying the equation:

$\alpha_{i}=\frac{\left\{S_{i}\right\}}{\Sigma\left\{S_{i}\right\}} \quad i=1,2,3$

where

$\Sigma \mathrm{Si}=\left\{\left\{\begin{array}{c}\mathrm{Py}^{+} \mathrm{Cr} \\ -\mathrm{Py}^{+} \mathrm{Cl}^{-}\end{array}\right\}+\left\{\begin{array}{l}-\mathrm{Py}^{+} \\ \left.\mathrm{PHCl}_{4}\right]^{2-}\end{array}\right\}+\left\{\begin{array}{l}\mathrm{Py}^{+}-\mathrm{Py}^{+}\left[\mathrm{MCl}_{3}\right]^{-} \\ -\mathrm{Py}^{+}\left[\mathrm{MCl}_{3}\right]^{-}\end{array}\right\}\right.$

The dependencies of the distribution coefficients, $\alpha_{\mathrm{i}}$, of the surface complex species, $\mathrm{MCl}_{4}{ }^{2-}\left(\mathrm{S}_{2}\right)$ and $\mathrm{MCl}_{3}^{-}\left(\mathrm{S}_{3}\right)$, and the corresponding concentration of the free pendant center $\mathrm{SiPy}^{+} \mathrm{Cl}^{-}\left(\mathrm{S}_{1}\right)$ are shown in Figure 5 .

The calculated values of $\alpha_{i}$ for $\mathrm{CuCl}_{2}$ adsorption on $\mathrm{Si} 3 \mathrm{Py}^{+} \mathrm{Cl}^{-}$and $\mathrm{Si} 4 \mathrm{Py}^{+} \mathrm{Cl}^{-}$(Figure $4 \mathrm{a}$ and $4 \mathrm{c}$ ) and for $\mathrm{ZnCl}_{2}$ adsorption on $\mathrm{Si} 4 \mathrm{Py}^{+} \mathrm{Cl}^{-}$(Figure 4d) indicate that both species $\mathrm{MCl}_{4}{ }^{2-}$ and $\mathrm{MCl}_{3}{ }^{-}$are adsorbed on the adsorbents surface over the whole concentration range of $\mathrm{MCl}_{2}$ in solution. The correlation between stepwise equilibrium constants for these three cases (Table 3) is $\mathrm{K}_{(2)}^{2}<\mathrm{K}_{(2)}^{1}$, showing that the negative cooperativity effect is operating. In this case, the formation of $\mathrm{MCl}_{4}{ }^{2-}$ species $\left(\mathrm{S}_{2}\right)$ on the adsorbents surface reduces the affinity of the surface by $\mathrm{MCl}_{2}$, and consequently the formation of $\mathrm{MCl}_{3}^{-}$species $\left(\mathrm{S}_{3}\right)$, according to the reaction described in equation (4), 
Table 3. Calculated values of the adsorption capacity, $\mathrm{t}_{\mathrm{Q}}$, global stability constants, $\beta_{(2)}{ }^{\mathrm{i}}$, and stepwise stability constants, $\mathrm{K}_{(2)}{ }^{\mathrm{i}}$, based on the bidentate binding center model

\begin{tabular}{lcccc}
\hline & \multicolumn{2}{c}{${\mathrm{Si} 3 \mathrm{Py}^{+} \mathrm{Cl}^{-}}$} & \multicolumn{2}{c}{$\mathrm{Si}^{2} \mathrm{Py}^{+} \mathrm{Cl}^{-}$} \\
\cline { 2 - 5 } & $\mathrm{CuCl}_{2}$ & $\mathrm{ZnCl}_{2}$ & $\mathrm{CuCl}_{2}$ & $\mathrm{ZnCl}_{2}$ \\
\hline $\mathrm{t}_{\mathrm{Q}} / \mathrm{mmol} \mathrm{g}^{-1}$ & 0.41 & 0.32 & 0.44 & 0.48 \\
$\log \beta_{(2)}{ }^{1} \equiv \log \mathrm{K}_{(2)}{ }^{1}$ & $4.14(0.03)^{*}$ & $3.3(0.3)$ & $3.82(0.03)$ & $3.93(0.03)$ \\
$\log \beta_{(2)}{ }^{2}$ & $7.05(0.03)$ & $8.22(0.06)$ & $6.82(0.08)$ & $7.48(0.07)$ \\
$\log \mathrm{K}_{(2)}{ }^{2}$ & $2.91(0.04)$ & $4.9(0.3)$ & $3.00(0.09)$ & $3.55(0.08)$ \\
\hline
\end{tabular}

* The values in parenthesis are the standard deviations of parameters.
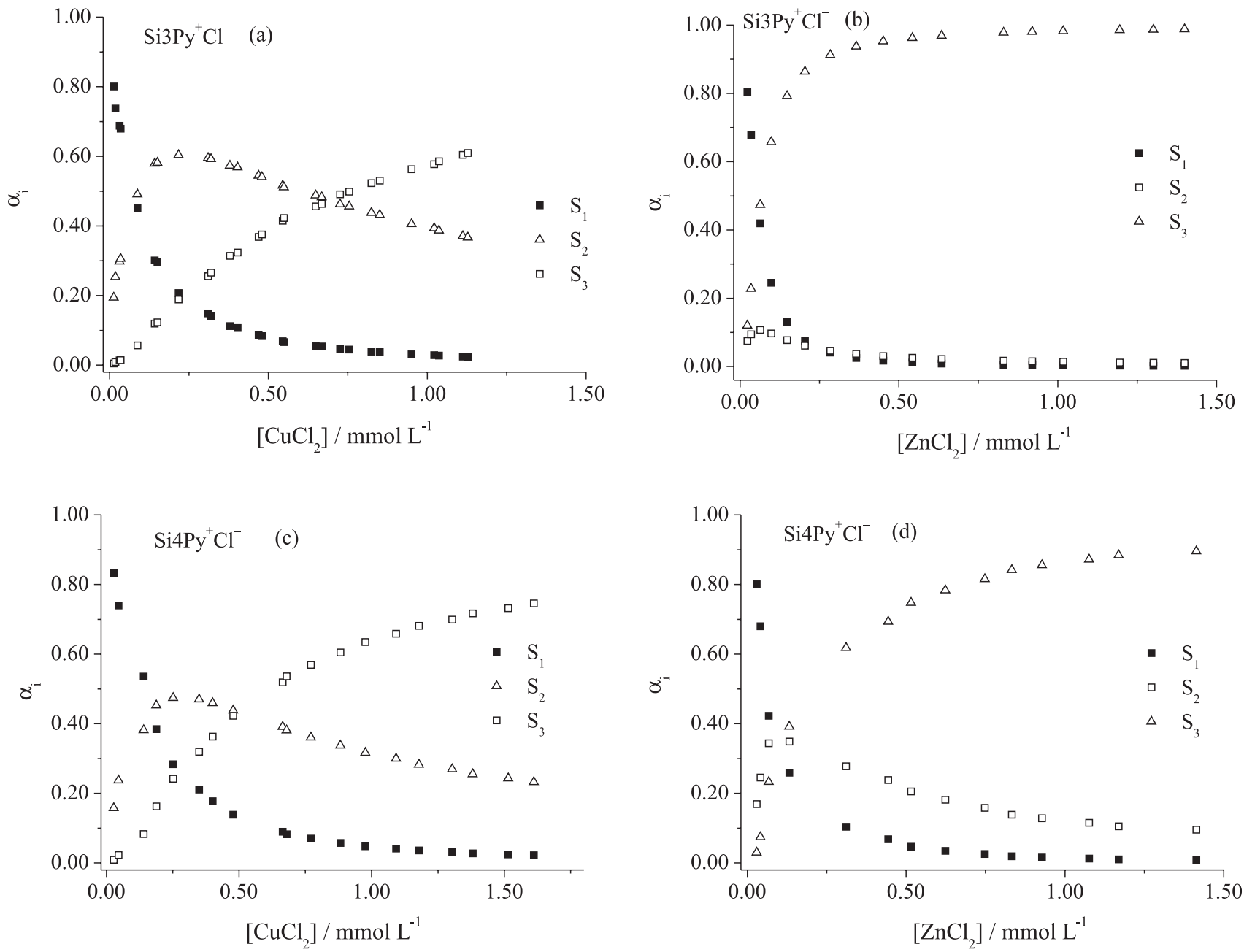

Figure 5. Plots of distribution coefficients, $\alpha_{i}$, of species $\left(\mathrm{S}_{1}\right),\left(\mathrm{S}_{2}\right)$ and $\left(\mathrm{S}_{3}\right)$ versus $\mathrm{MCl}_{2}$ concentrations in ethanol solutions: (a) $\mathrm{CuCl}_{2}$ and (b) $\mathrm{ZnCl}$ on $\mathrm{Si} 3 \mathrm{Py}^{+} \mathrm{Cl}^{-}$; (c) $\mathrm{CuCl}_{2}$ and (d) $\mathrm{ZnCl}_{2}$ on $\mathrm{Si}_{4} \mathrm{Py}^{+} \mathrm{Cl}^{-}$.

is depressed. For adsorption of $\mathrm{ZnCl}_{2}$ on $\mathrm{Si}_{3} \mathrm{Py}^{+} \mathrm{Cl}^{-}$(Figure $4 \mathrm{~b})$, Table 3 shows that $\mathrm{K}_{(2)}^{2}>\mathrm{K}_{(2)}^{1}$, indicating a positive cooperativity effect, i.e., adsorption and formation of $\mathrm{MCl}_{3}$ is enhanced in the presence of $\mathrm{MCl}_{4}{ }^{2-}$ in the adsorption site. $\mathrm{ZnCl}_{3}{ }_{3}^{-}$species is formed predominantly over the whole concentration range of $\mathrm{ZnCl}_{2}$ in the solution phase.

\section{Conclusions}

The new ion exchange polymers 3- $n$-propyl (3-methylpyridinium)silsesquioxane chloride and 3-n-propyl(4-methylpyridinium)silsesquioxane chloride were prepared and characterized by solid state ${ }^{13} \mathrm{C}$ NMR 
spectra, thermogravimetric and elemental analyses and by ionized chloride determination.

Adsorption of $\mathrm{ZnCl}_{2}$ and $\mathrm{CuCl}_{2}$ from ethanol solutions on the sorbent materials occurred considering that each center of adsorption was formed by two neighboring $\mathrm{SiPy}^{+} \mathrm{Cl}^{-}$functional groups spatially orientated as a bidentate ligand. Considering the ability of copper and zinc chlorides in forming $\mathrm{MCl}_{2+\mathrm{n}}{ }^{\mathrm{n}-}$ complexes ${ }^{46}$ the values of $\mathrm{t}_{\mathrm{Q}}$ and the two stepwise equilibrium constants were calculated for $\mathrm{MCl}_{2}$ adsorption on both $\mathrm{Si} 3 \mathrm{Py}^{+} \mathrm{Cl}^{-}$and $\mathrm{Si} 4 \mathrm{Py}^{+} \mathrm{Cl}^{-}$solid surfaces. The simulations demonstrated that, for systems where the negative cooperativity effects are observed, both $\mathrm{MCl}_{3}{ }^{-}$and $\mathrm{MCl}_{4}{ }^{2-}$ species can coexist on the surface, except for $\mathrm{ZnCl}_{2}$ adsorption on $\mathrm{Si} 3 \mathrm{Py}^{+} \mathrm{Cl}^{-}$, where positive cooperativity is observed.

Taking into account the high affinity shown by both materials, $\mathrm{Si} 3 \mathrm{Py}^{+} \mathrm{Cl}^{-}$and $\mathrm{Si} 4 \mathrm{Py}^{+} \mathrm{Cl}^{-}$, to $\mathrm{Cu}^{\mathrm{II}}$ and $\mathrm{Zn}^{\mathrm{II}}$ chlorides, the novel silsesquioxane polymers modified with 3- and 4-methylpyridinium chloride are potentially useful in adsorption processes of these metals and extensible for other similar metal halides.

\section{Acknowledgments}

HAM is indebted to FAPESP for a pos-doctoral fellowship, NF to PIBIC-CNPq for an undergraduate student fellowship, and YG to FAPESP for financial support (grant 00-11103-5).

\section{References}

1. El-Naggar, I. M.; Abou-Mesalam, M. M.; J. Hazard. Mater. 2007, 149, 686.

2. Pavan, F. A.; Costa, T. M. H.; Benvenutti, E. V.; Colloids Surf., A 2003, 226, 95.

3. Valcárcel, M.; Cárdenas, S.; Simonet, B.M.; Moliner-Martínez, Y.; Lucena, R.; Trends Anal. Chem. 2008, 27, 34.

4. Goyal M.; Rattan, V. K.; Aggarwal, D.; Bansal, R. C.; Colloids Surf. 2001, 190, 229.

5. Wang, S.; Boyjoo, Y.; Choueib, A.; Zhu, Z. H.; Water Res. 2005, 39, 129.

6. Yasukawa, A.; Yokoyama, T.; Kandori, K.; Ishikawa, T.; Colloids Surf., A 2007, 299, 203.

7. Baytak, S.; Turker, A. R.; Microchim. Acta 2005, 149, 109.

8. Sirola, K.; Laatikainen, M.; Paatero, E.; Colloids Surf., A 2007, 296, 158.

9. Dias Filho, N. L.; Gushikem, Y.; Sep. Sci. Technol. 1997, 32, 2535.

10. Moreira, J. C., Gushikem, Y., Anal. Chim. Acta 1985, 176, 263.

11. Dias Filho, N. L.; Carmo, D. R.; Rosa, A. H.; Electrochim. Acta 2006, 52, 965 .
12. Dias Filho, N. L. in: Encyclopedia of Surface and Colloid Science, vol. 1, $2^{\text {nd }}$ ed., Taylor \& Francis: New York, 2006, p. 229.

13. Dias Filho, N. L.; Carmo, D. R.; in Encyclopedia of Surface and Colloid Science, vol. 1, $2^{\text {nd }}$ ed., Taylor \& Francis: New York, 2006, p. 209.

14. Dias Filho, N. L.; Carmo, D. R.; Rosa, A. H.; Sep. Sci. Technol. 2006, 41, 733.

15. Fonseca, M. G.; Espínola, J. G. P.; Oliveira, S. F.; Santos, L. C. R.; Souza, A. G.; Airoldi, C.; Colloids Surf., A 1998, 133, 205.

16. Gomes, L. A. M.; Padilha, P. M.; Moreira, J. C.; Dias Filho, N. L.; Gushikem, Y.; J. Braz. Chem. Soc. 1998, 9, 494.

17. Deschler, U.; Kleinschmit, P.; Panster, P.; Angew. Chem. Int. Ed. Engl. 1986, 25, 236.

18. Alfaya, R. V. S.; Gushikem, Y.; J. Colloid Interface Sci. 1999, 213,438 .

19. Lazarin, A. M.; Gushikem, Y.; J. Braz. Chem. Soc. 2002, 13, 88.

20. Splendore, G.; Benvenutti, E. V.; Kholin, Y. V.; Gushikem, Y.; J. Braz. Chem. Soc. 2005, 16, 147.

21. Pavan, F. A.; Franken, L.; Moreira, C. A.; Costa, T. M. H.; Benvenutti, E. V.; Gushikem, Y., J. Colloid Interface Sci. 2001, $241,413$.

22. Shea, K. J.; Loy, D. A.; Chem. Mater. 2001, 13, 3306.

23. Pavan, F. A.; Hoffmann, H. S.; Gushikem, Y.; Costa, T. M. H.; Benvenutti, E. V.; Mater. Lett. 2002, 55, 378.

24. Schubert, U.; Hüsing, N.; Lorenz, A.; Chem. Mater. 1995, 7, 2010.

25. Im, H. J.; Yang, Y.; Allain, L. R.; Barnes, C. E.; Dai, S.; Xue, Z.; Environ. Sci. Technol. 2000, 34, 2209.

26. Lee, B.; Kim, Y.; Lee, H.; Yi , J.; Microporous Mesoporous Mater. 2001, 50, 77.

27. Gushikem, Y.; Benvenutti, E. V.; Kholin, Y. V.; Pure Appl. Chem. 2008, 80, 1593.

28. Burleigh, M. C.; Dai, S.; Hagaman, E. W.; Lin, J. S.; Chem. Mater. 2001, 13, 2537.

29. Vaghetti, J. C. P.; Zat, M.; Bentes, K. R. S.; Ferreira, L. S.; Benvenutti, E. V.; Lima, E. C.; J. Anal. At. Spectrom. 2003, 18, 376.

30. Gushikem, Y.; Moreira, J. C.; J. Colloid Interface Sci. 1985 , 107, 70 .

31. Gushikem, Y.; Moreira, W. C.; Colloids Surf. 1987, 25, 155.

32. Alfaya, R. V. S.; Fujiwara, S. T.; Gushikem, Y.; Kholin, Y. V.; J. Colloid Interface Sci. 2004, 269, 32.

33. Pissetti, F. L.; Magosso, H. A.; Yoshida, I. V. P.; Gushikem, Y.; Myernyi, S. O.; Kholin, Y. V.; J. Colloid Interface Sci. 2007, 314, 38.

34. Lucho, A. M. S.; Panteleimonov, A. V.; Kholin, Y. V.; Gushikem, Y.; J. Colloid Interface Sci. 2007, 310, 47.

35. Kholin, Y.; Zaitsev, V.; Pure Appl. Chem. 2008, 80, 1561.

36. Gushikem, Y.; Magosso, H. A.; Fattori, N.; Br PI 0703801-1, 2007. 
37. Yang, J.; El-Nahhal, I.; Maciel, G. E.; J. Non-Cryst. Solids 1996 204, 105.

38. Bayer, G.; Albert, K.; Reiners, J.; Nieder, M.; J. Chromatogr. 1983, 264, 197.

39. Maciel, G. E.; Sindorf, D. W.; Bartuska, V. J.; J. Chromatogr. 1981, 205, 438 .

40. Silverstein, R. M.; Bassler, G.C.; Morrill, T.C.; Identificação Espectrométrica de Compostos Orgânicos, 6th ed., Livros Técnicos e Científicos: Rio de Janeiro, 2000.

41. Selvakumar, K.; Vancheesan, S.; Polyhedron 1995, 14, 2091.

42. Giovagnini, L.; Marzano, C.; Bettio, F.; Fregona, D.; J. Inorg. Biochem. 2005, 99, 2139.

43. Kova'cs, A.; J. Mol. Struct. 1999, 482, 397.

44. Lazarin, A. M.; Landers, R.; Kholin, Y. V.; Gushikem, Y.; J. Colloid Interface Sci. 2002, 254, 31.
45. Adamson, A. W.; Gast, A. P.; Physical Chemistry of Surfaces, $6^{\text {th }}$ ed., Wiley-Interscience: USA, 1997.

46. Braibanti, A., Fisicaro, E.; Compari, C.; Ghiozzi, A.; Rao, R. S.; Rao, G. N.; React. Funct. Polym. 1998, 36, 245.

47. Lucho, A. M. S., Panteleimonov, A. V., Kholin, Y. V.; Gushikem, Y.; J. Colloid Interface Sci. 2007, 310, 47.

48. Merny, S. A.; Konyaev, D. S.; Kholin, Y. V.; Kharkov University Bulletin 1998, 420, 112.

49. http://www.bestnet.kharkov.ua/kholin/clinp.html, accessed in April 2008.

Received: November 12, 2008

Web Release Date: April 30, 2009

FAPESP helped in meeting the publication costs of this article. 